\title{
The Effect of Intrathecal Baclofen on the Lower Urinary Tract in Paraplegia
}

\author{
A. Talalla, MD FRCS, ${ }^{1}$ D. Grundy, FRCS, ${ }^{2}$ R. Macdonell, MB BS FRACP ${ }^{3}$ \\ ${ }^{1}$ McMaster University, Hamilton, Ontario, Canada, ${ }^{2}$ The Duke of Cormwall Spinal \\ Treatment Centre, Salisbury, ${ }^{3}$ Department of Neurology, The London Hospital, UK.
}

\section{Summary}

The effect of intrathecal baclofen on urethral pressure was investigated in 6 spinal cord injured patients. Although the response was inconsistent, and further studies are necessary to define its role more clearly in the bladder management of these patients, its possible application as an alternative to sensory rhizotomy to improve bladder emptying in patients having sacral nerve stimulation procedures is discussed.

Key words: Spasticity, Intrathecal baclofen, Urethral pressure, Spinal cord injury.

Afferent bombardment of the decentralised spinal cord is a major cause of spasticity. Penn and Kroin in $1984^{1}$ showed that a continuous intrathecal infusion of baclofen effectively controlled severe spasticity in spinal cord damaged patients. They further reported in $1987^{2}$ that bladder function also improved in some of their patients, but no formal studies of lower urinary tract function were undertaken.

It seemed to us a reasonable presumption that intrathecal baclofen might be improving bladder emptying in these patients by relieving spasticity of the striatal component of the external urethral sphincter. If this proved to be the case, it could also be of potential use in sacral nerve stimulation techniques in patients with detrusor sphincter dyssynergia due to spinal cord damage. Our interest in baclofen's possible role in reducing urethral pressure stemmed from one of the author's (AT) experience with extradural sacral nerve stimulation for restoring bladder control in spinal cord injured patients with detrusor hyperreflexia. He treated 7 such patients by coupling electrodes to the sacral nerves in their intraspinal but extradural course. Three patients voided urine in response to sacral nerve stimulation, and 1 of these voided effectively for 8 months, when inexplicably the voiding suddenly became inefficient, with unacceptably high residual volumes. The remaining 4 patients failed to void. ${ }^{3}$

We believe that the cause of this failure was the stimulation of sensory axons in 1989. 
the mixed nerve, an inevitable part of the extradural technique. It is possible that sensory volleys entering the decentralised spinal cord trigger uncontrolled sacral sphincteric reflexes that are an impediment to stimulation-induced voiding.

The major neuroanatomical difference between the so far unsuccessful extradural sacral nerve stimulation procedure and the successful intradural anterior root technique of Brindley ${ }^{4,5}$ is that in the intrathecal technique, sacral sensory axons are excluded from the stimulation.

If the surgically safer extradural technique is to be pursued, the logical next step is to prevent sensory volleys due to stimulation of the mixed nerve from entering the spinal cord. One of us (AT) has performed a surgical intradural sensory rhizotomy to no avail in 1 patient. However, Brindley ${ }^{5}$ has shown that bladder emptying, using his intradural technique, is enhanced by dividing the sensory nerve roots, which diminishes or abolishes reflex detrusor activity and increases bladder capacity. More recently he and other workers have reported that bilateral section of the S2, 3 and 4 sensory roots also abolishes detrusor-sphincter dyssynergia (Brindley, personal communication, 1989). They felt that because of these benefits, a sensory rhizotomy ought to be done in all female and most male patients having sacral anterior root stimulators, despite the disadvantages that it abolishes reflex erection, reflex ejaculation and sacral segment sensation if these were present.

However, some patients resent further damage to their nervous system and are reluctant to undergo surgical sacral sensory rhizotomy. We would prefer a physiological reversible solution to this problem, hence this study to investigate whether intrathecal baclofen could function as a reversible pharmacological sensory rhizotomy.

\section{Patients and methods}

Six male patients with complete paraplegia or quadriplegia due to spinal cord injury were studied. All had been injured for at least 6 months, and the detrusor and pudendal motor neurone pools had been demonstrated to be intact by the observation of normal latencies and amplitudes of the bulbocavernosus reflex. Previous combined urodynamics and fluoroscopy (videourodynamics) had confirmed the presence of reflex detrusor activity with detrusor-sphincter dyssynergia. At the time of the study, 4 patients managed their bladder dysfunction by condom drainage and 2 practised intermittent self-catheterisation. None had had surgery on their urinary tracts.

Every patient had varying degrees of muscle spasticity. Three were taking baclofen orally, in one instance in combination with dantrolene. Another patient was taking dantrolene alone and 2 were not on antispasticity drugs. All oral baclofen was discontinued 24 hours before the study. Dantrolene was also discontinued in the 2 patients, 6 hours prior to the study.

Informed consent having been obtained, a fine catheter was introduced into the intrathecal space, using a 17 French gauge Hustead spinal needle. Urodynamic studies were then conducted in the supine position, using a DISA 21006 channel videourodynamic system. Dynamic urethral pressures were measured during bladder filling at a continuous rate of $40 \mathrm{ml}$ per minute, using a DISA 6-French 
dual pressure sensor catheter tip transducer. Simultaneous measurements of bladder and rectal pressures were made.

Following this, $1 \mathrm{ml}$ of CSF was withdrawn and $25 \mathrm{ug}$ baclofen in $1 \mathrm{ml}$ normal saline administered. Further boluses of baclofen were administered up to a total of $100 \mathrm{ug}$ and urodynamic studies performed after each bolus.

The degree of tone in the lower limbs was measured before and after the administration of baclofen by an independent observer, using the 5-point Ashworth scale (Table I).

Table I Five Point Ashworth scale for measuring muscle tone

\begin{tabular}{cl}
\hline Grade & \multicolumn{1}{c}{ Degree of muscle tone } \\
\cline { 2 - 2 } 1 & No increase in tone \\
2 & Slight increase in tone, giving a 'catch' when affected part is moved in flexion or \\
3 & extension \\
4 & More marked increase in tone but affected part easily flexed \\
5 & Considerable increase in tone; passive movement difficult \\
\hline
\end{tabular}

\section{Results}

\section{Effect on lower limb muscle tone}

The degree of muscle tone in the lower limbs was significantly reduced or abolished, as measured on the 5 point Ashworth scale, following intrathecal baclofen, in all patients (Table II). There was also a significant reduction in the ratio between the maximum amplitude $H$-reflex and $M$ response from calf muscles, the so called $H$ $\max / \mathrm{M} \max$ ratio. ${ }^{6}$

\section{Maximum urethral pressure}

The maximum urethral pressure was greatly reduced in 2 patients (Table III,

Table II Lower limb muscle tone before and after intrathecal baclofen

\begin{tabular}{|c|c|c|c|c|c|}
\hline Patient & $\begin{array}{c}\text { Neurological } \\
\text { level }\end{array}$ & $\begin{array}{l}\text { Time since } \\
\text { injury in } \\
\text { months }\end{array}$ & $\begin{array}{l}\text { Normal oral } \\
\text { medication } \\
\text { for spasticity }\end{array}$ & $\begin{array}{l}\text { Ashworth } \\
\text { grade of } \\
\text { muscle tone } \\
\text { before } \\
\text { intrathecal } \\
\text { baclofen }\end{array}$ & $\begin{array}{l}\text { Ashworth } \\
\text { grade of } \\
\text { muscle tone } \\
\text { after } \\
\text { intrathecal } \\
\text { baclofen }\end{array}$ \\
\hline 1 & T6 & 10 & $\begin{array}{l}\text { baclofen } \\
20 \mathrm{mg} \text { tds }\end{array}$ & 4 & 3 \\
\hline 2 & $\mathrm{~T} 11$ & 39 & $\begin{array}{l}\text { baclofen } \\
20 \mathrm{mg} 5 \text { times } \\
\text { daily dantrolene } \\
75 \mathrm{mg} \text { tds }\end{array}$ & 4 & 1 \\
\hline 3 & $\mathrm{~T} 10$ & 6 & nil & 2 & 1 \\
\hline 4 & $\mathrm{C} 4$ & 6 & nil & 3 & 1 \\
\hline 5 & $\mathrm{~T} 10$ & 15 & $\begin{array}{l}\text { baclofen } \\
30 \text { mg qds }\end{array}$ & 4 & 1 \\
\hline 6 & T5 & 27 & $\begin{array}{l}\text { dantrolene } \\
50 \mathrm{mg} \text { qds }\end{array}$ & 4 & 3 \\
\hline
\end{tabular}


Fig. 1). In the remaining 4 patients, there was a slight reduction (2 patients) or slight increase ( 2 patients) i.e. no significant change.

\section{Maximum detrusor pressure}

In the 2 patients with a great reduction in maximum urethral pressure, there was also a significant reduction in maximum detrusor pressure-from 128 to 20 and from 86 to $50 \mathrm{cms} \mathrm{H}_{2} \mathrm{O}$ respectively (Table IV). This was presumably partly a reflection of the decreased urethral resistance. Two other patients also showed a fall in maximum detrusor pressure following intrathecal baclofen.

\section{Effect on bladder emptying and residual urine}

No conclusion could be made, although patient number 2, who had the most marked reduction of maximum urethral pressure (253-26 $\mathrm{cms}_{2} \mathrm{O}$ ), also had a dramatic reduction of residual urine from 240 to $25 \mathrm{ml}$. One patient was unable to void during the study (patient number 3 ) and in the remaining 4 patients there was no significant change in the residual urine. Patient number 4 asked that the study be abandoned before all the pressure measurements following intrathecal baclofen were able to be completed.

\section{Effect on erection}

Three patients noticed that reflex erections were reduced or abolished for at least 24 hours following intrathecal baclofen, 2 noticed no change and 1 was undecided (Table V).

\section{Discussion}

Reversible means of chronically interrupting sensory nerve signals have until recently been clinically impracticable.

Electrophysiological techniques such as anode block, ${ }^{4,7}$ collision block with unidirectionally generated action potentials ${ }^{8,9,10}$ and very high frequency stimulation block $^{11,12}$ are clinically untested and potentially damaging to nerve tissue.

One of us (AT) has attempted selective local anaesthetic blockade of sacral afferent fibres to no avail. A possible alternative to local anaesthetic nerve conduction block is by pharmacologically depressing the deleterious sphincteric reflexes in the decentralised sacral spinal cord.

The gamma-aminobutyric acid (GABA) analogue baclofen is widely used orally for relief of skeletal muscle spasticity, ${ }^{13}$ but its usefulness has been limited by its poor ability to cross the blood-brain and blood-spinal cord barriers and by side effects resulting from its interaction with brain centres. ${ }^{2,13}$

However, when baclofen is applied directly to spinal neurones by iontophoresis or by topical application to the exposed cord, it can induce both pre-synaptic and post-synaptic inhibition. ${ }^{14,15}$ When administered intrathecally into the CSF, it can greatly depress the excitability of spinal reflexes in a dose-dependent manner in intact experimental animals. ${ }^{16}$ 
Table III Maximum urethral pressure before and after intrathecal baclofen

\begin{tabular}{cccc}
\hline Patient & $\begin{array}{c}\text { Maximum urethral } \\
\text { pressure }\left(\mathrm{cms} \mathrm{H}_{2} \mathrm{O}\right) \\
\text { before baclofen }\end{array}$ & $\begin{array}{c}\text { Total dose of } \\
\text { baclofen }\end{array}$ & $\begin{array}{c}\text { Maximum urethral } \\
\text { pressure }\left(\mathrm{cms} \mathrm{H}_{2} \mathrm{O}\right) \\
\text { after baclofen }\end{array}$ \\
\hline 1 & 65 & $25 \mu \mathrm{g}$ & 15 \\
2 & 253 & $50 \mu \mathrm{g}$ & 26 \\
3 & 25 & $75 \mu \mathrm{g}$ & 50 \\
4 & 86 & $75 \mu \mathrm{g}$ & 58 \\
5 & 56 & $100 \mu \mathrm{g}$ & 74 \\
6 & 39 & $50 \mu \mathrm{g}$ & 26 \\
\hline
\end{tabular}

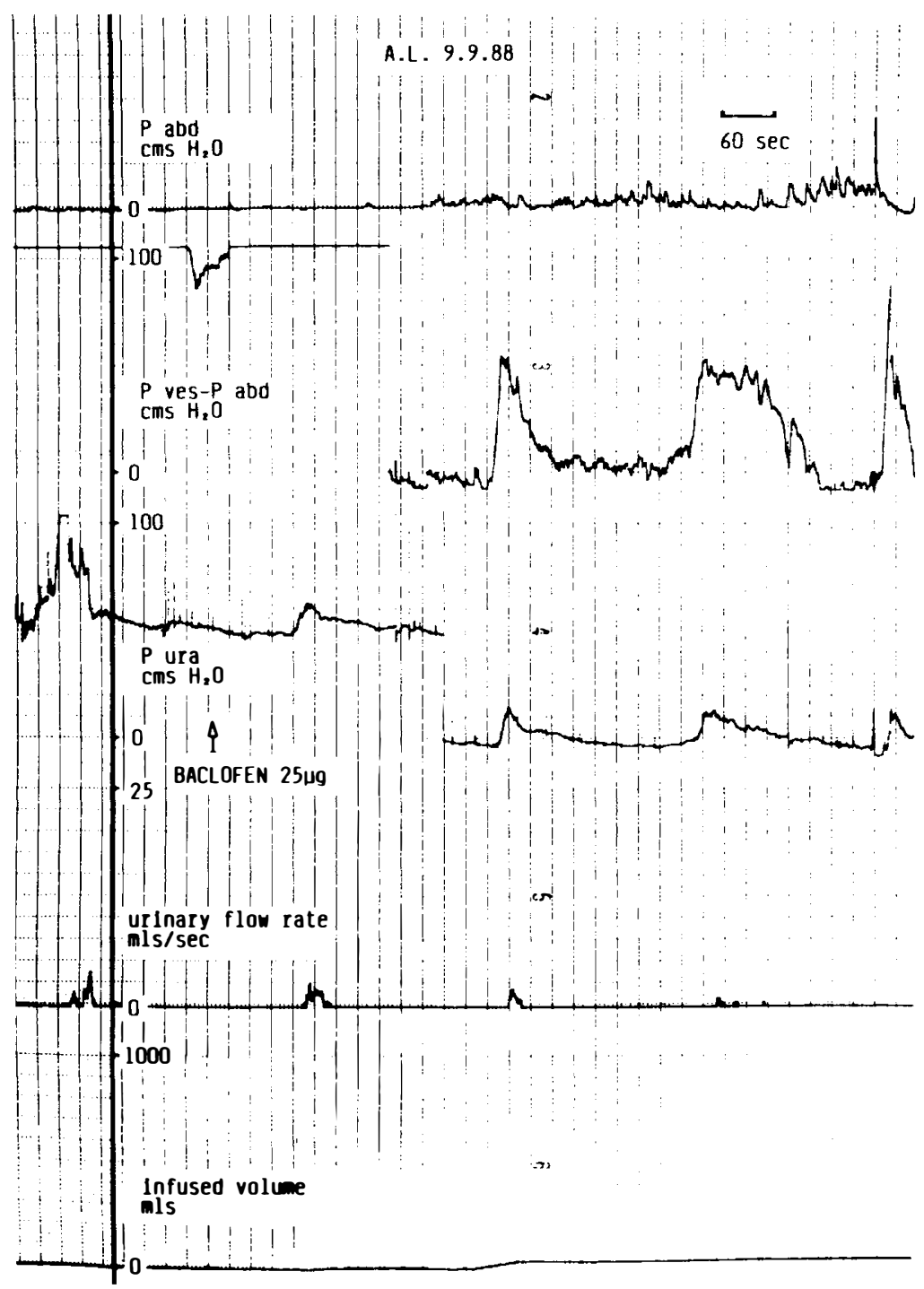

Figure 1 Reduction of urethral pressure ( $\mathrm{P}$ ura) from $65 \mathrm{~cm}$ to $15 \mathrm{~cm} \mathrm{H}_{2} \mathrm{O}$, following $25 \mu \mathrm{g}$ intrathecal baclofen 
Table IV Maximum detrusor pressure before and after intrathecal baclofen

\begin{tabular}{ccc}
\hline Patient & $\begin{array}{c}\text { Maximum detrusor } \\
\text { pressure }\left(\mathrm{cms} \mathrm{H}_{2} \mathrm{O}\right) \\
\text { before baclofen }\end{array}$ & $\begin{array}{c}\text { Maximum detrusor } \\
\text { pressure }\left(\mathrm{cms} \mathrm{H}_{2} \mathrm{O}\right) \\
\text { after baclofen }\end{array}$ \\
\hline 1 & 86 & 50 \\
2 & 128 & 20 \\
3 & 7 & 5 \\
4 & 146 & (figure unavailable) \\
5 & 70 & 24 \\
6 & 20 & 4 \\
\hline
\end{tabular}

Table $\mathbf{V}$ Effect of intrathecal baclofen on reflex penile erections

\begin{tabular}{|c|c|c|c|}
\hline Patient & $\begin{array}{l}\text { Strength of } \\
\text { erection before } \\
\text { baclofen }\end{array}$ & $\begin{array}{l}\text { Dose of } \\
\text { baclofen }\end{array}$ & $\begin{array}{l}\text { Strength of } \\
\text { erection after } \\
\text { baclofen }\end{array}$ \\
\hline 1 & weak & $25 \mu \mathrm{g}$ & unchanged \\
\hline 2 & normal & $50 \mu \mathrm{g}$ & reduced \\
\hline 3 & normal & $75 \mu \mathrm{g}$ & unchanged \\
\hline 4 & normal & $75 \mu \mathrm{g}$ & abolished \\
\hline 5 & weak & $100 \mu \mathrm{g}$ & not known \\
\hline 6 & weak & $50 \mu \mathrm{g}$ & abolished \\
\hline
\end{tabular}

The primary underlying mechanism for spinal spasticity is exaggeration of spinal reflexes. ${ }^{17}$ Although the effects of intrathecal baclofen are not completely understood, they are thought to result from its interaction with pre-synaptic GABA receptors on spinal primary afferents. This results in pre-synaptic inhibition of the sensory terminals in the cord, causing the interruption of reflex arcs. ${ }^{14,15}$ These understandings have led to clinical studies of the effects of intrathecal baclofen on spasticity. ${ }^{1,2,18-21}$

It is important to be aware that intrathecal baclofen delivered by an implanted drug delivery system has been associated with overdosage, resulting in drowsiness and coma, but this was shown to be due to malfunctioning of an earlier pump model. ${ }^{2}$

Recently, Frost et al., ${ }^{22}$ and Nanninga et al. ${ }^{23}$ reported an increase in bladder capacity and a reduction of detrusor-sphincter dyssynergia in patients with spinal cord paralysis. Some of their patients were able to stay dry on intermittent selfcatheterisation for the first time. We investigated intrathecal baclofen to see whether it could reduce urethral pressure and relieve detrusor-sphincter dyssynergia, so that its future use with extradural sacral nerve techniques might result in improved bladder emptying. Unfortunately, the extradural technique, ${ }^{3}$ which is a less major operation than Brindley's well established intradural anterior sacral root stimulator procedure, is not practicable at present, probably because stimulation of the mixed motor and sensory fibres of the sacral nerves, which is inherent in the technique, triggers off uncontrolled sacral sphincteric reflexes, resulting in detrusor-sphincter dyssynergia and poor voiding.

Our study confirmed that intrathecal baclofen very effectively reduces skeletal muscle tone in the spinal cord damaged patient. We showed that it can be effective 
in reducing urethral pressure, but the response of the urethral sphincter was inconsistent and could have resulted from one or both of the following factors:

Firstly, because radiological confirmation of the position of the intrathecal catheter tip was not obtained, it is possible that the drug was simply not correctly delivered to the sacral primary afferents.

Secondly, because the dose of baclofen was small, it is possible that larger doses would have had the desired effect on the urethral sphincter.

It should also be recognised that the human external urethral sphincter does not behave in all respects like other striated muscle structures.

A previously unreported side-effect of intrathecal baclofen was noted in at least half of our patients - that of reduced or abolished reflex penile erections. This effect was presumably due to the ability of baclofen to generally depress the excitability of spinal reflexes. This side effect has already resulted in a subsequent patient declining to have an intrathecal baclofen pump implanted, because of complete loss of reflex erections following a 50 ug test dose of intrathecal baclofen.

In spite of the possible deleterious effect of intrathecal baclofen on reflex erections, we believe that it undoubtedly has a place in treating spinal cord injured patients with severe spasticity. In addition, it appears to have an action on the lower urinary tract but further studies are required to define its role more clearly in the bladder management of these patients.

\section{Acknowledgements}

We wish to thank Ciba-Geigy Pharmaceuticals for provision of the baclofen, and the Wessex Regional Health Authority for their support in underwriting the cost of additional urodynamic equipment.

This study was supported in part by the NIH Neural Prosthesis Program, contract NO1-NS-5-2378.

\section{References}

1 Penn RD, Kroin JS. Intrathecal baclofen alleviates spinal cord spasticity. Lancet 1984: 1:1078.

2 Penn RD, Kroin JS. Long-term intrathecal baclofen infusion for treatment of spasticity. J Neurosurg 1987: 66:181-185.

3 Talalla A, Bloom JW, Nguyen Q. Successful intraspinal extradural sacral nerve stimulation for bladder emptying in a victim of traumatic spinal cord transection. Neurosurgery 1986: 19:955961.

4 Brindley GS, Polkey CE, Rushton, DN. Sacral anterior root stimulators for bladder control in paraplegia. Paraplegia 1982: 20:365-381.

5 Brindley GS, Polkey CE, Rushton DN, Cardozo L. Sacral anterior root stimulators for bladder control in paraplegia: the first 50 cases. J Neurol Neurosurg Psychiatry 1986: 49:1104-1114.

6 Macdonell RAL, Talalla A, Swash M, Grundy D. Intrathecal baclofen and the H-reflex. J Neurol Neurosurg Psychiatry 1989: 52:1110-1112.

7 Brindley GS, Craggs MD. A technique for anodally blocking large nerve fibres through chronically implanted electrodes. J Neurol Neurosurg Psychiatry 1980: 43:1083-1090.

8 Van-Den-Honert C, Mortimer JT. Generation of unidirectionally propagated action potentials in a peripheral nerve by brief stimuli. Science 1979: 206:1311-1312.

9 Van-Den-Honert C, Mortimer JT. A technique for collision block of peripheral nerve: single stimulus analysis. IEEE Transactions on Biomedical Engineering 1981a: 28:373-378.

10 Van-Den-Honert C, Mortimer JT. A technique for collision block of peripheral nerve: frequency dependence. IEEE Transactions on Biomedical Engineering 1981b: 28:379-382.

11 Tanner JA. Reversible blocking of nerve conduction by alternating-current excitation. Nature 1962: 195:712-713.

12 Solomonow M. External control of the neuromuscular system. IEEE Transactions on Biomedical Engineering. 1984: 31:752-763.

13 Hattab JR. Review of European clinical trials with baclofen. In: Feldman RG, Young RR, Koella WP (eds). Spasticity: Disordered motor control. Miami Symposia specialists. 1980: 71-75. 
14 Davidoff RA, Sears ES. The effects of Lioresal on synaptic activity in the isolated spinal cord. Neurology 1974: 24:957-963.

15 Price GW, Wilkin GP, Turnbull MJ, Bowery NG. Are baclofen-sensitive GABA $A_{B}$ receptors present on primary afferent terminals of the spinal cord? Nature 1984: 307: 71-74.

16 Kroin JS, Penn RD, Beissinger RL, Arzbaecher RC. Reduced spinal reflexes following intrathecal baclofen in the rabbit. Ex Brain Res 1984: 54:191-194.

17 Dimitrijevic MR. Spasticity-clinical and neurophysiological entity or alteration in sensory motor behaviour. In: Fields WS (ed). Neural organisation and its relevance to prosthetics. New York: International Medical Book Corporation. 1973: 61-73.

18 Penn RD, Kroin JS. Continuous intrathecal baclofen for severe spasticity. Lancet 1985: 2:125127.

19 Dralle D, Muller YH, Zierski J, Klug N. Intrathecal baclofen for spasticity. Lancet 1985: 2:1003.

20 Hankey GJ, Stewart-Wynne EG, Perlman D. Intrathecal baclofen for severe spasticity. Med J Aus 1986: 145:465-466.

21 Müller H, Börner U, Zierski J, Hempelmann G. Intrathecal baclofen in tetanus. Lancet 1986: $1: 317-318$

22 Frost F, Nanninga J, Penn R, Savoy S, Wu Y. Intrathecal baclofen infusion. Effect on bladder management programs in patients with myelopathy. Am J Phys Med Rehabil 1989: 68:112-115.

23 Nanninga JB, Frost F, Penn R. Effect of intrathecal baclofen on bladder and sphincter function. J Urol 1989: 142:101-105. 